\title{
Влияние излучения видимого диапазона на проводимость тонких пленок одностенных углеродных нанотрубок
}

\author{
В.М. Ефимов, Е.Р. Закиров, Д.Г. Есаев \\ Институт физики полупроводников им. А.В. Ржанова СО РАН, Новосибирск, \\ 630090, просп. Ак. Лаврентьева, 13 \\ тел:+7 (913) 782-2695, эл. nочта: efimov@isp.nsc.ru
}

DOI 10.34077/RCSP2019-137

Тонкие пленки одностенных углеродных нанотрубок (ОУНТ) являются перспективным чувствительным материалом, для построения нового поколения широкого класса как фотоприемных так и химических и биосенсоров [1,2]. Сенсоры на основе ОУНТ обладают неоспоримым преимуществом перед существующими, поскольку, в перспективе, могут обеспечить высокую чувствительность наряду с очень малым энергопотреблением, простотой технологии изготовления и работой при комнатной температуре. Сочетание этих качеств является основой для разработки портативных сенсорных устройств для in-situ химического и биологического анализа. Ранее было показано, что электропроводность пленок ОУНТ является очень чувствительной к адсорбции $\mathrm{NH}_{3}$,

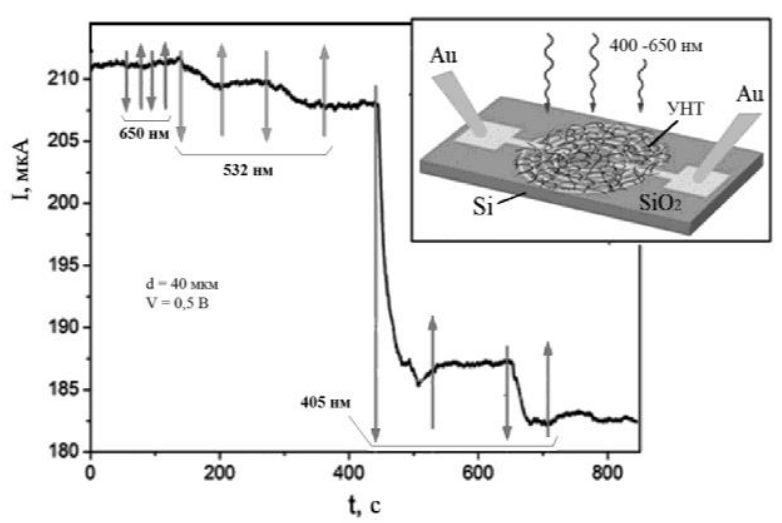

Рис.1 Изменение тока в КВШС структурах при засветке лазерным излучением: стрелка вверх- включение засветки, вниз выключение. $\mathrm{CO}, \mathrm{H}_{2}$ и $\mathrm{O}_{2}$, при этом восстановление сенсора (десорбция аналита) может быть ускорено УФоблучением $[3,4]$. В данной работе исследовалась проводимость тонких пленок разупорядоченных УНТ смешанного состава (металлического и полупроводникового типа проводимости). Одностенные углеродные нанотрубки были представлены фирмой OCSiAl (Новосибирск). Измерения проводились на круговых встречноштыревых структурах - КВШС (вставка на рис.1), изготовленных на окисленных кремниевых подложках стандартными методами взрывной фотолитографии по металлическому слою $(\mathrm{Cr}+\mathrm{Au})$. Слой ОУНТ наносился капельным методом из раствора ОУНТ в N-метил-2-пирролидоне. Засветка КВШС, с нанесенным на него слоем ОУНТ производилась лазерным излучением с тремя различными длинами волн: 650, 532 и 405 нм и соответствующей мощностью 5, 45 и 10 мВт. Основной фотоэлектрический эффект наблюдался для фиолетового излучения с длиной волны 405 нм.

Ранее было показано, что при облучении УФ светом происходит десорбция кислорода с поверхности нанотрубок.

Фотоэлектрические процессы, исследованные в работе, могут быть использованы для получения характеристик смешанных слоев, содержащих ОУНТ как металлического, так и полупроводникового типа проводимости. С практической точки зрения фотодесорбция, наблюдаемая при облучении пленок фиолетовым светом, может быть применена для ускоренного восстановления («очистки») газового наносенсора. Полученные результаты, также, могут быть использованы при разработке новых фотодетекторов и оптоэлектронных приборов.

\section{Лumepamypa}

[1] X. He et al. // Adv. Optical Mater. 2015. V.3. P.989-1011.

[2] R. Tang et al. // Sensors. 2017. V.17. P.882.

[3] L. Yang et al. // Proc. of $8^{\text {th }}$ Conference on Nanotechnology (Arlington, USA). 2008. P.284-287.

[4] R.J. Chen et al. // Appl. Phys. Lett. 2001. V.79. P.2258-2260. 